\title{
Indian Himalayan timberline ecotone in response to climate change - initial findings
}

\author{
S. P. Singh ${ }^{1, *}$, A. Bhattacharyya ${ }^{2}$, Amit Mittal $^{3}$, Aseesh Pandey ${ }^{4}$, Ashish Tewari ${ }^{3}$, \\ Avantika Latwal ${ }^{5}$, Bency David ${ }^{2}$, Bhupendra S. Adhikari ${ }^{6}$, Devendra Kumar ${ }^{4}$, \\ G. C. S. Negi ${ }^{5}$, Ishfaq Ahmad Mir ${ }^{7}$, Krishna Kumar Tamta ${ }^{3}$, Kumar Sambhav ${ }^{5}$, \\ Mayank Shekhar ${ }^{2}$, Mohit Phulara ${ }^{5}$, Munisa Manzoor ${ }^{7}$, Nandan Singh ${ }^{3}$, \\ Pankaj Tewari ${ }^{1}$, Parminder S. Ranhotra ${ }^{2}$, Pradeep Singh ${ }^{5}$, Pratap Dhaila ${ }^{1}$, \\ Priyanka Sah ${ }^{5}$, Rahul Kumar ${ }^{6}$, Rajesh Joshi ${ }^{5}$, Ranbeer S. Rawal ${ }^{5}$, Renu Rawal, \\ Ripu Daman Singh ${ }^{1}$, Shruti Shah ${ }^{3}$, Subrat Sharma ${ }^{5}$, Subzar Ahmad Nanda ${ }^{7}$, \\ Surabhi Gumber ${ }^{1}$, Utsa Singh ${ }^{2}$ and Zafar Reshi ${ }^{7}$ \\ ${ }^{1}$ Central Himalayan Environment Association, 6 Waldorf Compound, Mallital, Nainital 263 001, India \\ ${ }^{2}$ Birbal Sahni Institute of Palaeosciences, 53, University Road, Lucknow 226007 , India \\ ${ }^{3}$ Department of Forestry and Environmental Science, D.S.B. Campus, Kumaun University, Nainital 263001 , India \\ ${ }^{4}$ G.B. Pant National Institute of Himalayan Environment and Sustainable Development, Sikkim Regional Centre, Pangthang, \\ Gangtok 737 101, India \\ ${ }^{5}$ G. B. Pant National Institute of Himalayan Environment and Sustainable Development (GBPNIHESD), Kosi-Katramal, Almora 263 643, India \\ ${ }^{6}$ Department of Habitat Ecology, Wildlife Institute of India, P.O. Box 18, Chandrabani, Dehradun 248 001, India \\ ${ }^{7}$ Department of Botany, University of Kashmir, Srinagar 190 006, India
}

This article enumerates the findings of a team research on the Indian Himalayan timberline ecotone, with focus on three sites (located in Kashmir, Uttarakhand and Sikkim). Timberline elevation increased from west to east, was higher in the warmer south aspect than the cooler north aspect, and was generally depressed. Betula, Abies, Rhododendron and Juniperus were important treeline genera. The Himalaya has not only the highest treelines (Juniperus tibetica, at $4900 \mathrm{~m})$, but also the widest elevational range $(>1700 \mathrm{~m})$. Remotely sensed data revealed that the timberline is a long, twisting and turning ecotone, traversing a length of 8-10 $\mathrm{km}$ per $\mathrm{km}$ horizontal distance. Surface temperature lapse rate in the monsoonal regions was lower $\left(-0.53^{\circ} \mathrm{C} / 100 \mathrm{~m}\right.$ elevation) than generally perceived and varied considerably with season, being the lowest in December. The Himalayan treeline species are not water-stressed at least in monsoonal regions, predawn tree water potential seldom getting below -1 MPa. The upward advance of Rhododendron campanulatum (a krummholz species) may deplete alpine meadows with climatic warming. Tree-ring chronology indicated that winter warming may be favouring Abies spectabilis. Early snowmelt increased growth period and species richness. Treelines generally are stable in spite of decades of warming. Dependence of people on timberline was still high; so economic interventions are required to reduce the same.

*For correspondence. (e-mail: surps@yahoo.com)
Keywords: Climate change, temperature lapse rate, timberline ecotone and elevation, tree water relation, treeline genera.

\section{Introduction}

UNDER the influence of global climate change, the Himalaya is warming at a higher rate than the global average rate $^{1-3}$. The rapid glacier melt is its major consequence, and a component of monitoring and research. At the lower edge of snowfields, there occurs the upper elevation limits of forests called timberlines, which too are highly sensitive to climatic warming, but somehow are among the least studied in the Himalaya. In contrast, timberlines and treelines are among the most intensively studied systems in Europe and USA. The remoteness of timberlines and treelines (they are located at higher elevations in the Himalaya than most other mountains, up to $4900 \mathrm{~m})^{4}$ could be one of the reasons for their being scantly researched. Changes in the cryosphere under the influence of global warming are likely to affect treeline areas and alpine meadows at community and ecosystem levels 5 . Heat deficiency with increase in elevation is considered to be the main cause of plants not attaining tree form beyond a certain elevation in mountains, and the formation of treeline. The treelines are linked to a growing season mean temperature of $6.7^{\circ} \mathrm{C} \pm 0.85^{\circ} \mathrm{C}$ in the mountains $^{6}$. Due to this critical temperature linkage, treelines are likely to show upslope rise under the influence of global warming ${ }^{7-10}$. 
According to Holtmeier ${ }^{11}$, timberline in mountains is generally regarded as the upper elevational limit of forests with crown cover, at least between $20 \%$ and $40 \%$. Above this occurs the treeline, which is identified as a line connecting the uppermost trees at a site ${ }^{11}$. According to this definition, a tree is generally an upright individual of a tree species with minimum height of $2 \mathrm{~m}$ or more ${ }^{12}$. The elevation width between timberline and treeline is often referred to as timberline or treeline ecotone. Individual trees may grow still higher, but their form is no longer tree-like; they become stunted and contorted, with several stems, and with twisted and gnarled branches. This could be termed as tree species line.

Studies on the Himalayan treelines are scarce and isolated. To address this shortcoming, the present study on the Himalayan treeline has taken a multi-site, multipartner and multidisciplinary approach (under the National Mission on Himalayan Studies of the Ministry of Environment, Forest and Climate Change, Government of India). Our objectives were: to map timberline at a regional level using remote-sensing techniques, estimate surface temperature lapse rate (TLR) based on observed data along elevation transects, analyse altitudinal pattern of vegetation leading to the treeline ecotone, document and analyse plant phenological responses to climate change, examine whether timberline trees are affected by water stress, study the relationship between tree ring growth and climate change, understand the impact of early snowmelt on species composition and plant community characters and growth, and to examine the scope of livelihood interventions at local community level in conservation and management of timberline resources.

\section{Material and methods}

Occupying about $11^{\circ}$ of latitudinal range and $31^{\circ}$ of longitudinal range (Figure 1), the Himalayan region (plus Hindu Kush) is not only massive, but also highly heterogeneous. Precipitation generally varies from less than $300 \mathrm{~mm}$ in some of the rainshadow areas in the north of the main Himalayan range to more than $4000 \mathrm{~mm}$ in monsoon-drenched southern slopes of the Eastern Himalaya. Generally, monsoon weakens from the east to west; however, conditions also vary locally in each part area because of topographic factors. In the areas shielded by high mountains, the monsoon months (June-September) account for less than $40 \%$ of annual rainfall, the Kashmir valley surrounded by the high Pir Panjal ranges being a typical example of this. However, in much of the outer ranges the monsoon months (June-September) account for $70-80 \%$ of annual rainfall. The Himalaya is warming at a rate significantly higher than global average rate, and the warming rate is increasing with altitude ${ }^{2,13,14}$. For detailed observations, we selected three sites located in Kashmir (dry with weak monsoon), Uttarakhand (UK; moist with strong monsoon) and Sikkim (wet with strong monsoon) (Figure 1).

\section{Remote sensing method for regional timberline mapping}

Satellite images of Landsat 8 (multispectral, spatial resolution of $30 \mathrm{~m}$ ) were used to generate regional-scale timberline maps. For a fine-resolution mapping of watershed, two different high-resolution satellite images were used (see Latwal et al. ${ }^{15}$ for details).

\section{Surface temperature lapse rate}

To estimate TLR, ten portable ONSET HOBO Pro-V2 microbloggers and six RG-200 tipping bucket rain gauges (Global Water make; 8" dia.) were installed along an elevation gradient from 1500 to $3680 \mathrm{~m}$ at N-W and S-E of Tungnath, Uttarakhand (see Joshi et al. ${ }^{16}$ for details).

\section{Vegetation along elevation gradient leading to timberline}

The selected altitudinal transects (e.g. 2200-3800 m in Kashmir) were divided into $100 \mathrm{~m}$ elevation bands (e.g. 17 in Kashmir). Three plots of $50 \times 50 \mathrm{~m}$ area each were established in each of these altitudinal bands. In each such plot ten $(10 \times 10 \mathrm{~m})$ quadrats for trees, $20(5 \times 5 \mathrm{~m})$ for shrubs and $40(1 \times 1 \mathrm{~m})$ for herbs were laid randomly for vegetation sampling ${ }^{17-19}$.

\section{Phenology}

Phenological observations on various phenophases were made on five species (Abies spectabilis, Betula utilis, Quercus semecarpifolia, Rhododendron arboreum, and Rhododendron campanulatum) at a monthly interval ${ }^{20}$.

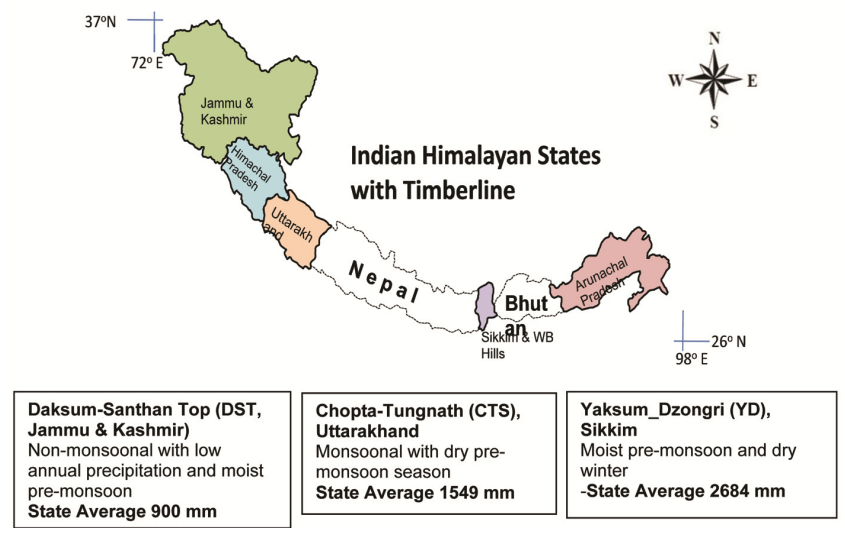

Figure 1. The three timberline study sites covering much of the range of variation across the Himalayan Arc, and representing three precipitation regimes (courtesy: Subrat Sharma, GBPNIHESD, Almora). 


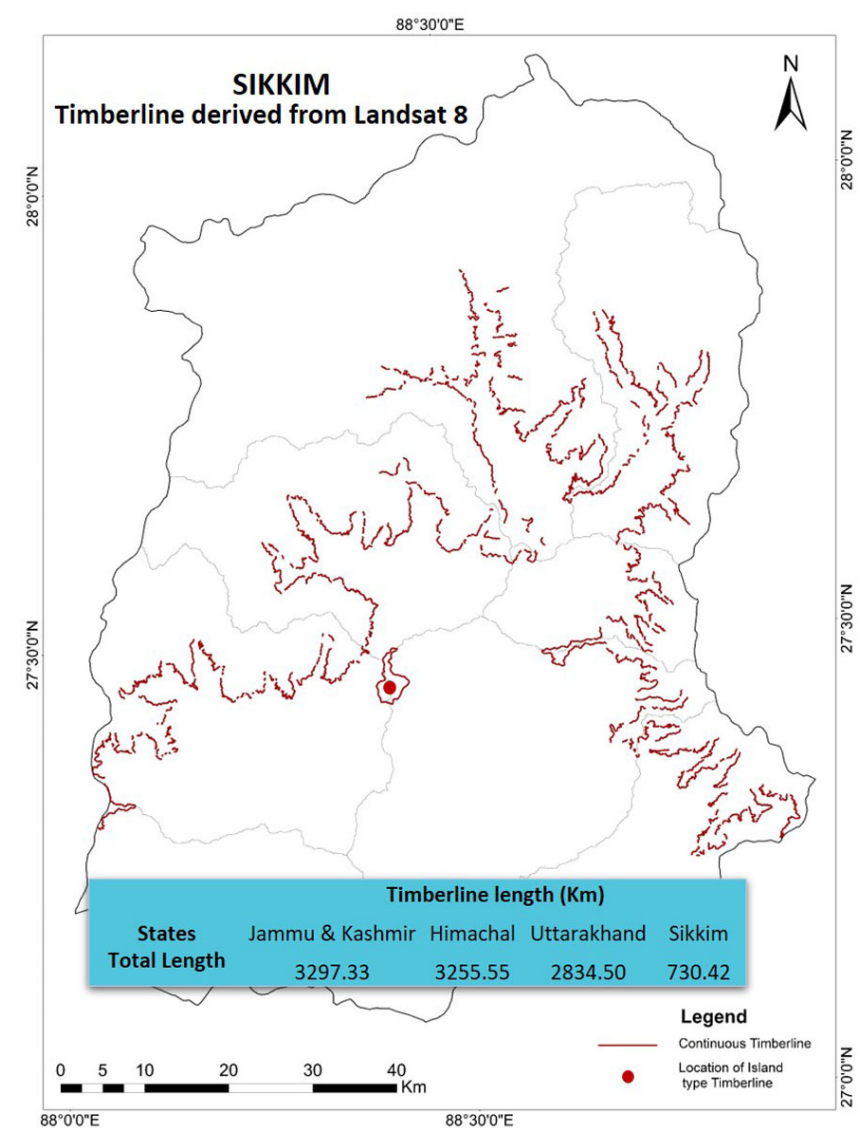

Figure 2. A view of highly curving and twisting timberline in the Himalaya derived from LISS IV (5.8 m spatial resolution).

\section{Tree water relation}

Tree water potential $(\Psi)$, pressure volume curves and leaf conductance were measured on five representative individuals of each of the selected tree species across the seasons $^{21}$.

\section{Tree ring width chronology}

This was based on about 300 tree core samples from 153 silver fir trees at Tungnath. Apart from this, 125 fir trees were measured for GBH to assess the girth class distribution $^{22}$.

\section{Early snowmelt effect}

To determine the effect of snow on vegetation, we selected two slopes with different snow cover: (i) 70 $80 \%$ cover, referred to as high snow cover (HSC), and (ii) $30-40 \%$ cover, referred to as low snow cover (LSC). The snow cover lasted for at least 20-25 days longer in the HSC site than the LSC site ${ }^{23}$.

\section{Livelihood interventions}

We conducted interviews at the household level, Focus Group Discussions (FGDs), individual interviews, meetings and discussions with village representatives to collect information regarding the dependence of people on forest resources. Compact area approach was adopted for implementation of livelihood interventions, and to gear up activities for entrepreneur development and ensuring market access ${ }^{24}$. Based on PRA, FGDs and discussions with allied stakeholders, the main options were categorized.

The cost-benefit analysis of each intervention (at a demonstration scale) was worked out ${ }^{25}$. The interventions were: off-season vegetable cultivation under polyhouses, vermin-composting, floriculture, rainwater harvesting, mushroom cultivation, training for making modern ringal handicraft, etc.

\section{Results and discussion}

\section{Timberline mapping}

As revealed by mapping with remote sensing techniques, a timberline at the regional scale is a long, highly curved line, full of turns and twists. However, much of the total length occurred within the mid-elevation ranges: $80.2 \%$ and $74.9 \%$ within $3200-3800 \mathrm{~m}$ in $\mathrm{HP}$ and UK respectively, and $82.7 \%$ within $3600-4200 \mathrm{~m}$ in Sikkim. 
Table 1. Various frontline species of timberline of Tungnath, Uttarakhand

\begin{tabular}{lccccc}
\hline & \multicolumn{5}{c}{ Elevation (m) } \\
\cline { 2 - 5 } Treeline type & Mean & SD & Minimum & Maximum & Length of treeline segment (km) \\
\hline Quercus semecarpifolia dominance & 3137 & 49 & 3068 & 3226 & 0.52 \\
Abies pindrow dominance & 3252 & 62 & 3068 & 3320 & 2.62 \\
Quercus semecarpifolia and mixed broadleaf & 3255 & 24 & 3205 & 3310 & 1.46 \\
Birch and mixed broadleaf & 3306 & 25 & 3257 & 3350 & 1.62 \\
Rhododendron arboreum and birch & 3340 & 65 & 3185 & 3460 & 1.69 \\
\hline
\end{tabular}

There was a tendency of increase in timberline elevation from the west to east. For example, the proportion of the total timberline length occurring in a relatively higher elevation band (3800-4000 $\mathrm{m}$ ) was $4.1 \%$ in HP, $15.8 \%$ in UK and $31.6 \%$ in Sikkim.

\section{Micro-level species distribution at Tungnath, Uttarakhand}

In Tungnath timberline-treeline ecotone the tree species were Abies pindrow, Abies spectabilis, Quercus semecarpifolia, Betula utilis, Rhododendron arboreum, R. campanulatum, Sorbus foliolosa, Prunus cornuta, Acer caesium and Viburnum grandiflorum. Each of them became frontline tree species at some sites. The upper limit of B. utilis-R. arboreum community was $3503 \mathrm{~m}$ (Table 1). Sorbus foliolosa (3286-3507 m), a small tree (3-5 m high) and $R$. camapnulatum, a krummholz species seem to take advantage of the warming as their seedlings and saplings often occurred beyond timberlines and treelines.

The length of timberline segment (tls) varied from $0.52 \mathrm{~km}$ for $Q$. semecarpifolia to 2.62 for $A$. pindrow (Table 1). These segments were zig-zag, running across $352 \mathrm{~km}(3068-3460 \mathrm{~m})$ within a small area of a few square kilometres. The mean elevation range of timberline varied from $3137 \mathrm{~m}$ for Q. semecarpifolia to $3340 \mathrm{~m}$ for mixed $R$. arboreum-B. utilis ecotone. Above the timberlines, trees occurred over varying elevation, ranging between 94 and $221 \mathrm{~m}$; these can be denoted as the elevation widths of treeline ecotone. In Sikkim, the elevation width of treeline ( $A$. densa-dominated) was from 0 to $155 \mathrm{~m}$ (ref. 26).

\section{Surface temperature lapse rate}

Detailed analysis of observed data from Tungnath shows that mean annual TLR was distinctly lower $\left(-0.53^{\circ} \mathrm{C} /\right.$ $100 \mathrm{~m})$ than the commonly used value $\left(-0.65^{\circ} \mathrm{C} / 100 \mathrm{~m}\right)^{16}$. It is likely that TLR has decreased recently because of global warming, which causes enhanced elevationdependent warming (EDW; according to this, the warming rate is greater in higher elevation areas than lower elevation areas). TLR varies significantly with season, being much lower in December $\left(-0.24^{\circ} \mathrm{C} / 100 \mathrm{~m}\right)$ than during pre-monsoon (March-May, $-0.64^{\circ} \mathrm{C} / 100 \mathrm{~m}$ ) and other months. TLR also changes with aspect, being lower in the warmer south aspect than cooler north aspect, and higher for maximum than minimum temperature (Figure 3). The lower TLR for minimum temperature could be related to more EDW. The low TLR might have accounted for high treelines in the Himalaya.

Using $-0.53^{\circ} \mathrm{C}$ TLR rate we estimate that treeline can go approximately up to $4000 \mathrm{~m}$ which is higher than the summit height. Thus, the entire alpine meadow at Tungnath will be converted into forest if climatic timberline could be attained.

\section{Vegetation along elevation gradients leading to timberline ecotone}

Kashmir: The vegetation of the entire elevation transect (2200-3700 m) consisted of 441 plant species, with eight tree species, one liana, 20 shrubs, and sub-shrubs and 218 herbs (Table 2). Among lower plants there were 33 pteridophytes, four liverworts, 35 mosses and 155 lichens (70 crustose, 71 foliose, 7 fruticose and 7 leprose). The total plant species richness (per $100 \mathrm{~m}$ elevation band) as well as of various groups tended to show a wavy pattern, and a marginal decline with altitude (Figure $4 a$ ). Lichens formed a sloping broad plateau from 2400 to $3600 \mathrm{~m}$; in this most species had broad elevational range, resulting in a constantly high species richness (from 38 to 52 species). In contrast, there were 46 herb species confined to a single $100 \mathrm{~m}$ elevation band; they are likely to be most threatened by climate change.

The total species number as well as the species number of various taxonomical groups declined monotonically from closed forest to alpine meadow (Figure $4 \mathrm{~b}$ ). The total species count was 294, 232 and 170 in closed forest, timberline ecotone and alpine meadow sections respectively (Figure $4 a$ ).

Uttarakhand: There were 1471 species with 106 trees, 233 shrubs and 1132 herbs in the three study elevation transects (2000-3500 m). A majority of these species $(203,52.5 \%)$ were Himalayan natives of which $39.1 \%$ are near-endemics to the Himalaya. Nativity across life-forms was $47.4 \%$ for herbs, $59.3 \%$ for trees and $68.2 \%$ for 


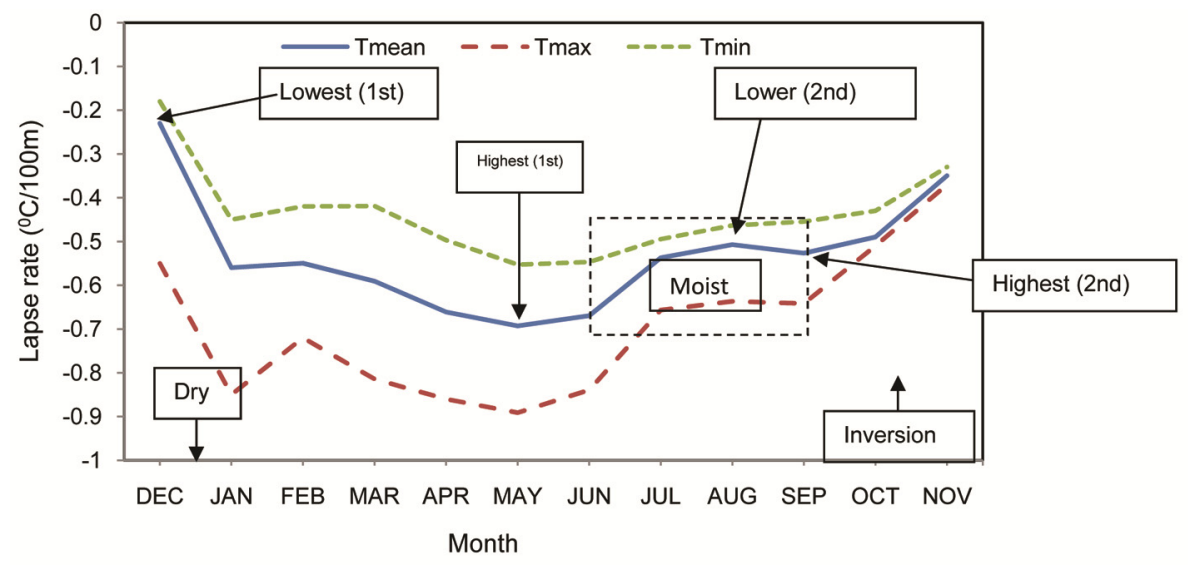

Figure 3. Annual cycle of maximum, minimum and mean temperature lapse rate (TLR) on NW aspect.

Table 2. Species richness and total tree basal area in high-elevation regions approaching treeline at the three study sites. Site-specific features and species counts in elevation transects are also mentioned

\begin{tabular}{|c|c|c|c|}
\hline & Kashmir & Uttarakhand & Sikkim \\
\hline $\begin{array}{l}\text { Elevational transect-name, } \\
\text { elevation, latitude, } \\
\text { longitude, mean annual } \\
\text { temperature, and annual } \\
\text { precipitation }\end{array}$ & $\begin{array}{l}\text { Daksum-Sinthon top } \\
\text { transect, } 33^{\circ} 36^{\prime} 43^{\prime \prime} \mathrm{N}, \\
75^{\circ} 26^{\prime} 6^{\prime \prime} \mathrm{E} ; 2200-3800 \mathrm{~m} \\
\text { (within } 40 \mathrm{~km} \text { ); } 12.8^{\circ} \mathrm{C}, \\
\text { and } 1035 \mathrm{~mm}\end{array}$ & $\begin{array}{l}\text { Tungnath-Chopta Tungnath (CT) } \\
\text { transect, } 30^{\circ} 30^{\prime} 76^{\prime \prime}-30^{\circ} 27^{\prime} 59^{\prime \prime} \mathrm{N}, \\
79^{\circ} 05^{\prime} 59^{\prime \prime}-79^{\circ} 16^{\prime} 55^{\prime \prime} \mathrm{E} ; 2000- \\
3500 \mathrm{~m} \text {. At } 3300 \mathrm{~m} \text { (timberline } \\
\text { ecotone); } 6.7 \pm 0.7^{\circ} \mathrm{C} \text {, and } \\
2410 \mathrm{~mm}\end{array}$ & $\begin{array}{l}\text { Yuksum-Dzongri transect, } 3000-4000 \mathrm{~m} \\
\text { Khangechendzonga National Park (KNP), } \\
\text { Sikkim, } 27^{\circ} 03^{\prime} 41^{\prime \prime}-28^{\circ} 7^{\prime} 34^{\prime \prime} \mathrm{N}, \\
88^{\circ} 03^{\prime} 40^{\prime \prime}-88^{\circ} 57^{\prime} 19^{\prime \prime} \mathrm{E} ; 5.68^{\circ} \pm 1.79^{\circ} \mathrm{C} \\
\text { and } 1021 \pm 157.01 \mathrm{~mm}\end{array}$ \\
\hline Total species & $\begin{array}{l}\text { A sloping, wavy plateau } \\
\text { with peaks and three } \\
\text { troughs; the highest } \\
\text { peak of } 139 \text { species at } \\
2500 \mathrm{~m}\end{array}$ & - & $\begin{array}{l}\text { Overall, a declining pattern with elevation } \\
\left(R^{2}=0.74\right)\end{array}$ \\
\hline Tree & $\begin{array}{l}\text { 8; hump-shaped, wavy } \\
\text { curve, peak at } 2400 \mathrm{~m} \text {; } \\
\text { then sharp decline }\end{array}$ & $\begin{array}{l}\text { 24-29; a little hump at } 2500 \mathrm{~m} \text { in } \\
\text { a declining species richness }\end{array}$ & $\begin{array}{l}\text { 23; a sloping plateau from } 3000-3800 \mathrm{~m} \text {, } \\
\text { which it declines rapidly; overall pattern is } \\
\text { declining }\end{array}$ \\
\hline Shrub & $\begin{array}{l}20 \text {; tends to increase with } \\
\text { elevation, with three } \\
\text { troughs and four peaks }\end{array}$ & $\begin{array}{l}\text { 26; increases with elevation } \\
\text { almost monotonically }\end{array}$ & $\begin{array}{l}\text { 22; peaks at } 3200 \mathrm{~m} \text {; thereafter declines } \\
\text { up to } 3400 \mathrm{~m} \text {, followed by a plateau }\end{array}$ \\
\hline Herb & $\begin{array}{l}218 \text { (including meadows); } \\
\text { wavy with four peaks } \\
\text { and three troughs, a mild } \\
\text { increase with elevation }\end{array}$ & $\begin{array}{l}\text { 138; increases with elevation, } \\
\text { but with more scatter }\end{array}$ & $\begin{array}{l}\text { 64; concave curve with at least two troughs } \\
\text { in the middle (at } 3300 \text { and } 3500 \mathrm{~m} \text { ) }\end{array}$ \\
\hline Total tree basal area & - & $\begin{array}{l}67.0-74.8 \mathrm{~m}^{2} \text { ha }^{-1} \text { between } 2400 \\
\text { and } 2800 \mathrm{~m} ; 43 \mathrm{~m}^{2} \mathrm{ha}^{-1} \text { at } \\
3200 \mathrm{~m} \text { elevation }\end{array}$ & $\begin{array}{l}\text { Peak } 52.5 \mathrm{~m}^{2} \text { at } 3200 \mathrm{~m} \text {, with mean of } \\
19 \mathrm{~m}^{2} \mathrm{ha}^{-1} \text { for the entire elevation range, } \\
3000-4000 \mathrm{~m}\end{array}$ \\
\hline
\end{tabular}

shrubs. While the number of woody species declined sharply with increasing elevation, the number of herb species was relatively stable along the elevation gradient. The altitudinal decrease of species/genera ratio $(\mathrm{S} / \mathrm{G})$ in case of trees in the study area may imply their phylogenetic over-dispersion towards higher altitude. On the contrary, the increasing $\mathrm{S} / \mathrm{G}$ ratio of shrubs and herbs towards higher altitude implies phylogenetic clumping, indicating that diversification within the genera is more intense.

At the local level, 55 taxa with recorded low abundance and narrow ecological amplitude deserve greater attention for conservation ${ }^{27}$.
Sikkim: The widest elevation range was observed for A. densa (3000-3900 m) and S. microphylla (3100$3989 \mathrm{~m})^{18}$. In contrast, $R$. fulgens was confined to the upper end of the forest range. Tree species richness declined monotonically along the elevation gradient, with a small hump at $3400 \mathrm{~m}$ (Figure 5).

In Sikkim, treeline ecotone was studied in detail by sampling nine contiguous sites. It indicated that $A$. densa, $S$. microphylla and $R$. lanatum occurred at all the sites (Figure 6). In total, ten tree species occurred in the elevational transect, of which six were of rhododendrons. Compared to this, Kashmir and UK sites, with four and five tree species respectively, were much less species-rich. 


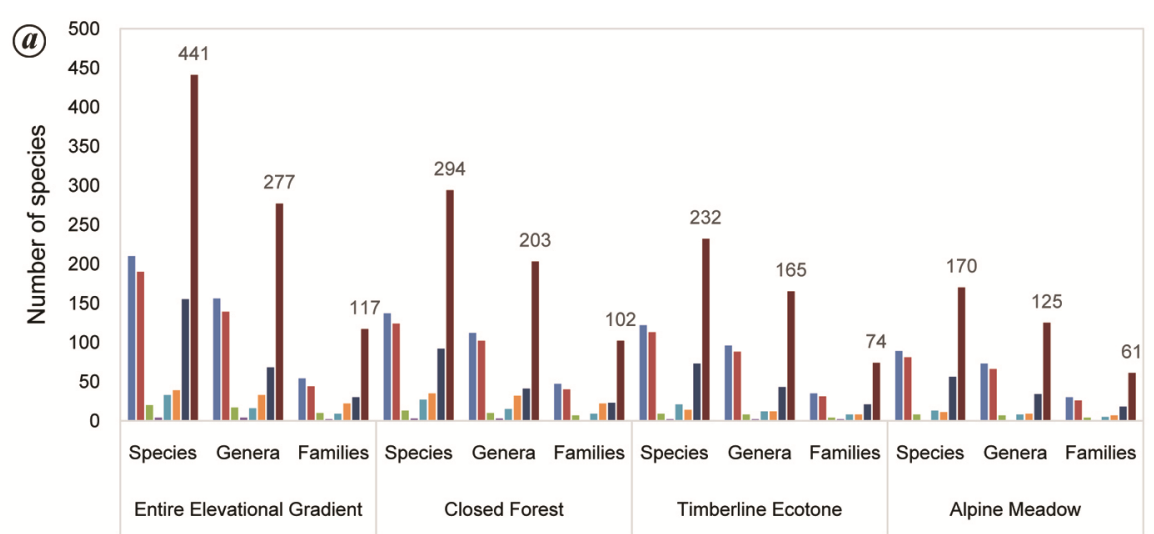

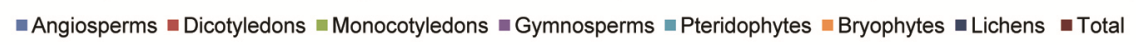

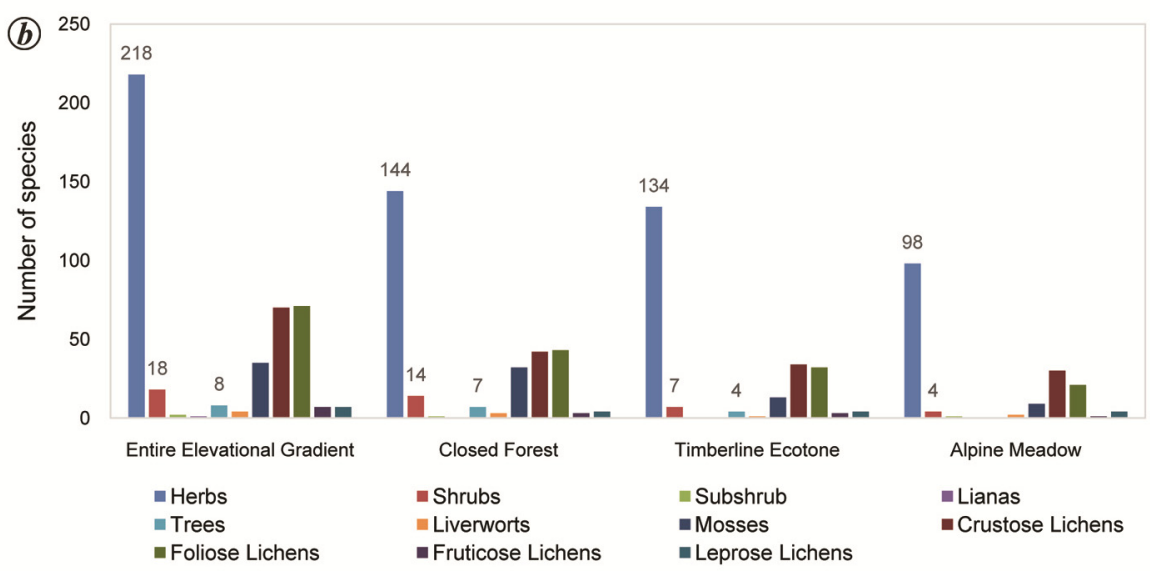

Figure 4. $\boldsymbol{a}, \mathrm{Kashmir}$ transect, Daksum Sinthan Top (2200-3800 m). Number of species, genera and families of different taxonomic groups. $\boldsymbol{b}$, Number of species belonging to different functional taxonomic groups. (a) and (b) the numbers are given separately for the entire transect, closed forest, timberline ecotone and alpine meadow.

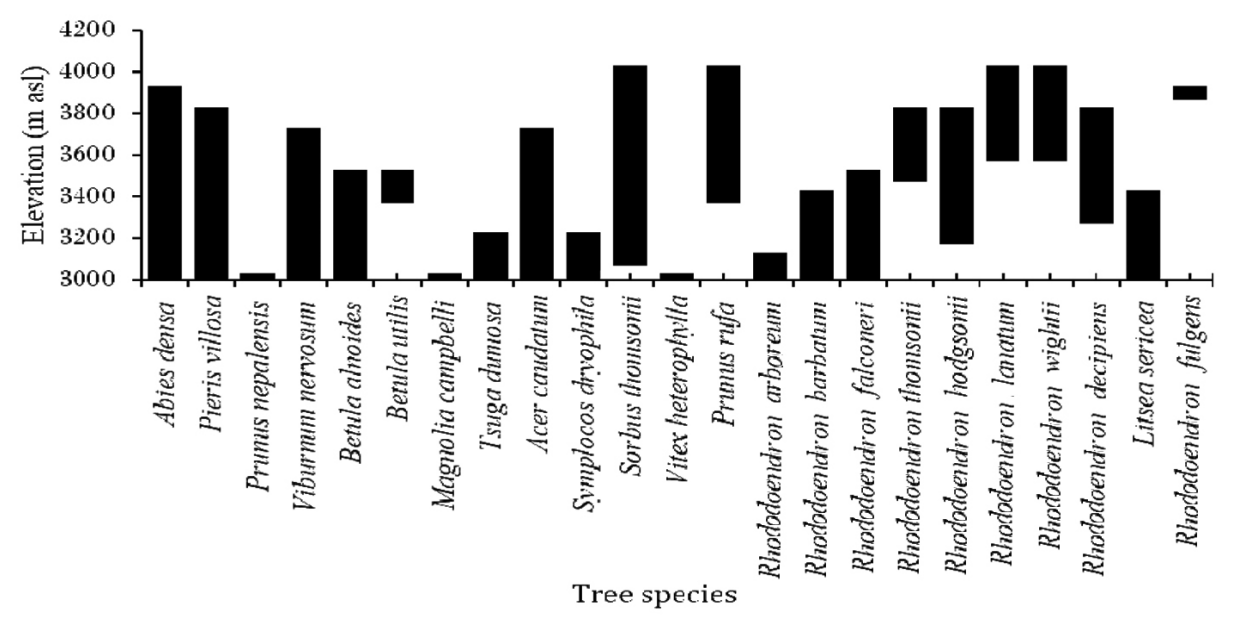

Figure 5. Elevational range of tree species across the subalpine forest of Khangchendzonga National Park (KNP), Sikkim.

Interestingly, birch was absent in the KNP site of Sikkim, and $R$. campanulatum occurred only occasionally.

Across the three study regions, shrub species number ranged between 18 and 26 . The herb species number increased from east (Sikkim, 64 species) to west (Kashmir,
218 species), while trees followed an opposite trend (Table 2).

In Sikkim, Ericaceae with 19 species was the most common family, while in the western Himalaya Compositae was the most important ${ }^{28}$. 


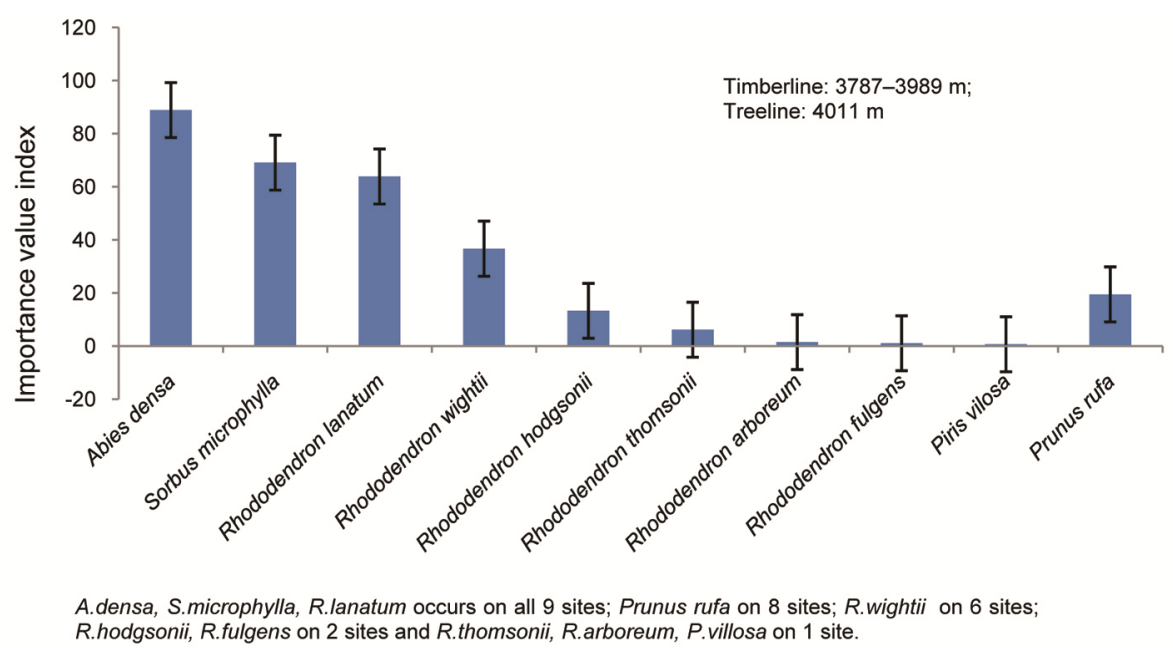

Figure 6. Average tree species importance value index (sum of relative frequency, density and basal area) across nine contiguous sites in KNP located within a distance of $20 \mathrm{~km}$ (ref. 26). Abies densa (up to $40 \mathrm{~m}$ ) is a tall canopy species and the remaining species are short, viz. $<10 \mathrm{~m}$.

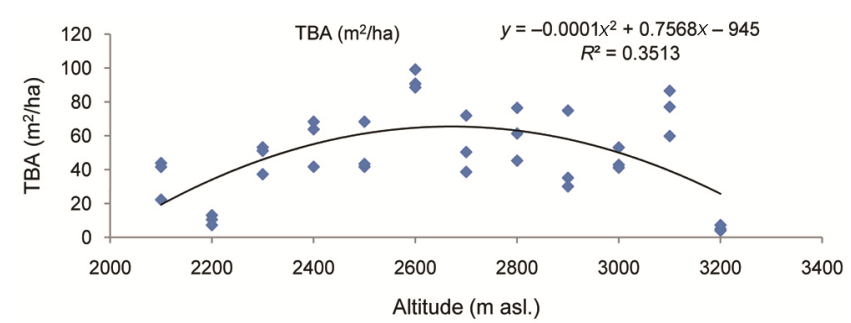

Figure 7. Distribution of tree basal area (TBA) across an altitudinal transect from mid-elevation forest to timberline in Uttarakhand, India.

\section{Tree density and distribution of seedlings and saplings}

The average tree density $\left(1504 \mathrm{ha}^{-1}\right)$ in treeline site of Sikkim of the present study was similar to that reported for another Sikkim site, $2800-3800 \mathrm{~m}$ transect $\left(1634 \mathrm{ha}^{-1}\right)$ by Acharya et al. $^{29}$, and was much higher than in the Western Himalaya $\left(546-728 \mathrm{ha}^{-1}\right)^{30,31}$. The high tree density in Sikkim could be largely due to the abundance of rhododendrons and other species with small trees. This is also indicated by much lower tree basal area in Sikkim (average $19.02 \mathrm{~m}^{2} \mathrm{ha}^{-1}$ ) than in the Western Himalaya (43 $\mathrm{m}^{2} \mathrm{ha}^{-1}$ up to $3200 \mathrm{~m}$ ). In Tungnath transect of Uttarakhand where there were several old-growth oak and fir forest stands, the tree basal area ranged between 67 and $75 \mathrm{~m}^{2} \mathrm{ha}^{-1}$ at $2400-2800 \mathrm{~m}$ elevation (Figure 7).

At Sikkim site seedling density decreased rapidly above $3800 \mathrm{~m}$, and at $4000 \mathrm{~m}$ elevation it was merely $331.3 \mathrm{ha}^{-1}$ compared to the average of $3036 \mathrm{ha}^{-1}$ for the entire elevation transect. The difference was similar for saplings $\left(360.0 \mathrm{ha}^{-1}\right.$ at $4000 \mathrm{~m}$ and $1601 \mathrm{ha}^{-1}$ average of the elevation transect) and trees $\left(306.7 \mathrm{ha}^{-1}\right.$ at $4000 \mathrm{~m}$ and $1504 \mathrm{ha}^{-1}$ average of the elevation transect). In
Uttarakhand, seedling density was relatively lower (generally below 2000/ha), and it declined rapidly with elevation.

Sampling of saplings and seedlings indicated a ten-fold decline in their numbers above $3800 \mathrm{~m}$. The lack of regeneration due to grazing seems to be a limiting factor for the upward march of treeline.

\section{Patterns in timberline vegetation along the Himalayan Arc}

From data collected for 145 timberline/treeline sites, the following features are apparent: (i) The compilation of data from various sources indicates the presence of 10 genera and 58 tree species in the Himalayan timberline ecotone. However, there is confusion about synonyms and species identification; so this number needs more authentication. (ii) The most commonly occurring genera are Juniperus (at 77 sites), Rhododendron (at 62 sites), Betula (at 53 sites) and Abies (at 48 sites). Occurring at 53 sites, Betula utilis (Himalayan birch) emerged as the characteristic tree species of the Himalayan treeline in much of the western and central regions. (iii) The Himalayan treeline is not only very high (Juniperus tibetica at $4900 \mathrm{~m}$, the highest in the Northern Himalaya), but also widely ranging in elevation $(>1700 \mathrm{~m})$, indicating that at many sites it is depressed possibly because of livestock grazing, and other anthropogenic and topographical factors. (iv) Timberline elevation tends to increase from NW to SE along the Himalayan Arc for most species. (v) Himalayan timberline is generally higher in the warmer south aspect than cooler north aspect. (vi) Himalayan timberline is higher in the central part of ranges than towards peripheral areas. All treeline forms described in the literature, abrupt, diffuse, finger and 


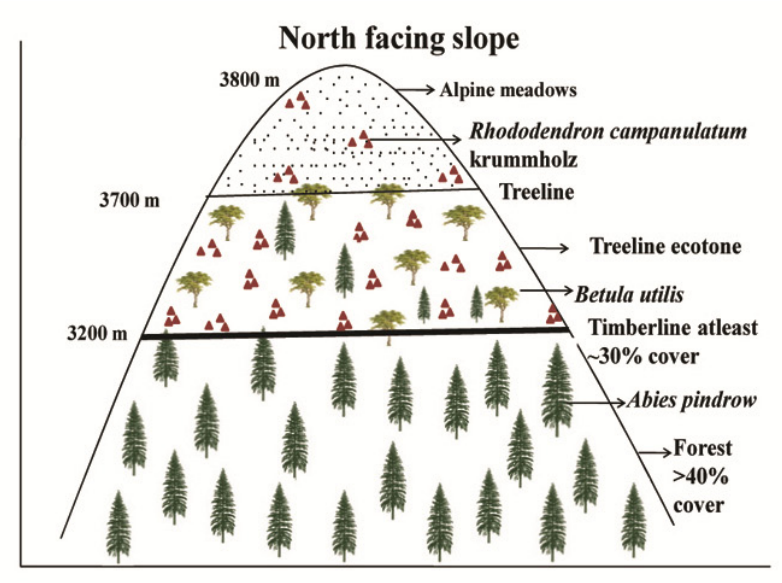

Uttarakhand

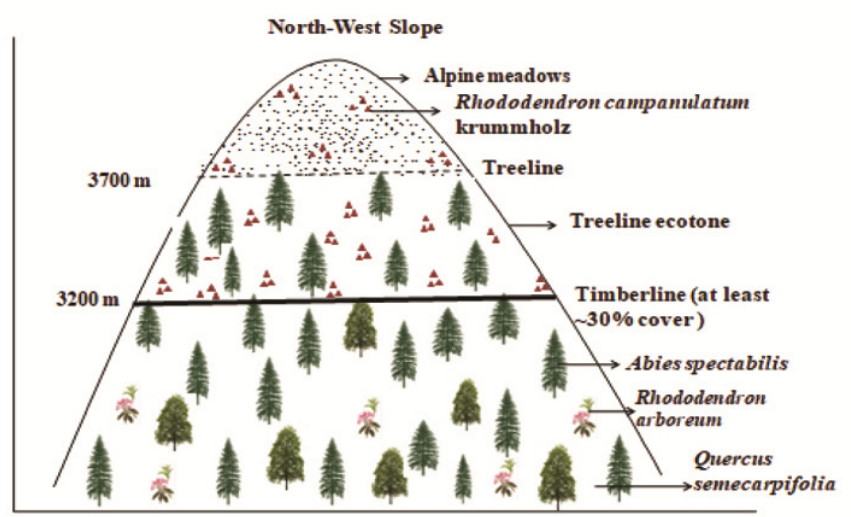

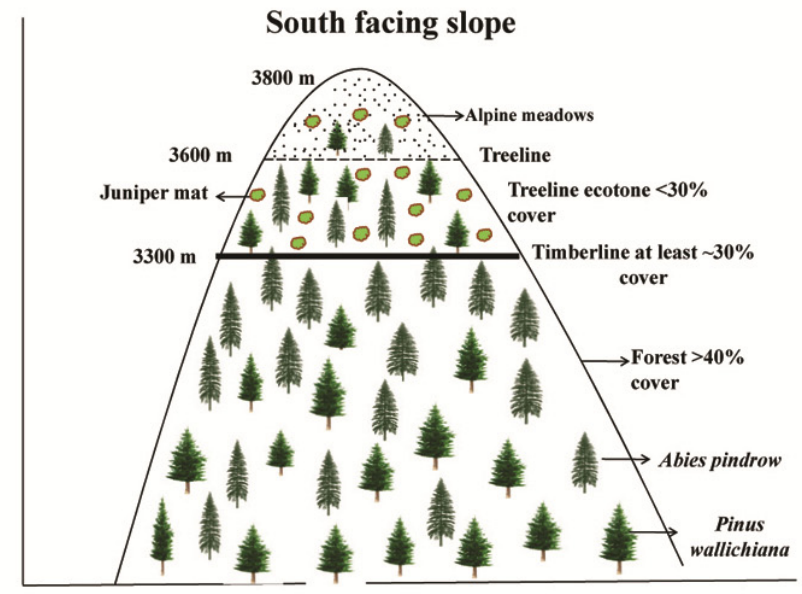

Sikkim

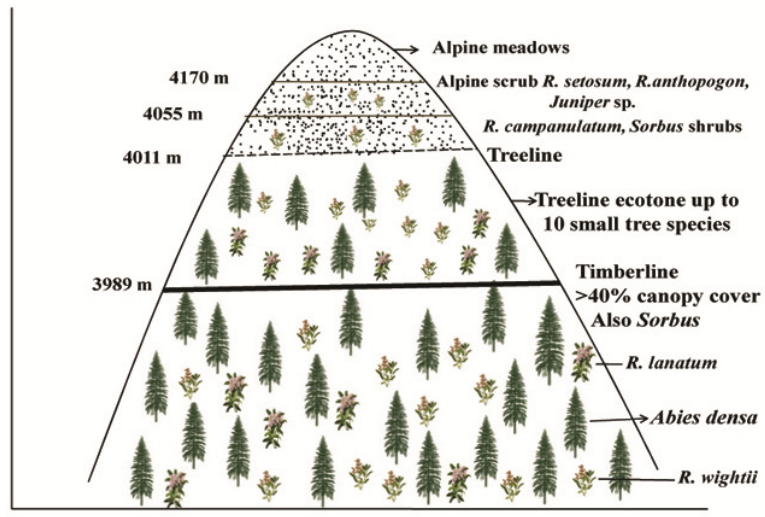

Figure 8. Representation of timberline and treeline species and their elevations in three study sites of Himalayas (Jammu and Kashmir, Uttarakhand and Sikkim).

island types occur in the Himalaya. However, a form may change within a treeline segment. For example, in Sikkim an $A$. densa-dominated treeline was abrupt type in one part and diffuse type in another part.

In Kashmir site, the treeline was $100 \mathrm{~m}$ higher in the south aspect than the north aspect. Here, the effect of aspect could also be seen on the ecotone species. In the moist northern aspect from lower to higher elevation, species pattern was as follows: fir alone, fir and birch mixed, and birch alone, while the drier southern aspect had fir and blue pine (Pinus wallichiana) (Figure 8). The number of tree species in the timberline ecotone increased from NW to SE end of the Himalaya.

\section{Phenology}

At Tungnath study site, mean atmospheric temperature for the growing period (July-September) has increased by about $1{ }^{\circ} \mathrm{C}\left(@ 0.11^{\circ} \mathrm{C} / \mathrm{yr}\right)$ during the last two decades (between 1990-97 and 2017). The mean growing season temperature at treeline $\left(11.2^{\circ} \mathrm{C}\right)$ was much higher than that ascribed to climatic treeline $\left(6.7^{\circ} \mathrm{C}\right)$. Soils were cooler than air temperature, and the difference between their temperatures increased during autumn from the lowest in August (Figure 9).

\section{Comparison with mod-elevation sites}

At Tungnath, maximum temperature occurred in August, compared to June in mid-elevation forests. The effect of delay in the time of maximum temperature can be seen in the delayed leaf initiation in treeline ecotone. A comparison of leaf and shoot growth of Quercus spp. and R. arboreum between the mid-altitude forests of this region and Tungnath site shows that bud-break and leafing take place about 4-6 weeks earlier at the mid-altitude site ${ }^{32}$. The leaf expansion within the first month of leafing in these species was conspicuously greater at the midaltitude site ( $83 \%$ versus $43 \%$ in Quercus spp., and $76 \%$ versus $49 \%$ in $R$. arboreum). A shorter shoot extension period (2-5 months versus 4-6 months) and lower shoot growth at the treeline ecotone for Quercus spp. and $R$. arboreum than at the mid-altitude site (mean shoot length $=5.6 \mathrm{~cm}$ versus $9.5 \mathrm{~cm}$ ) were the other striking 


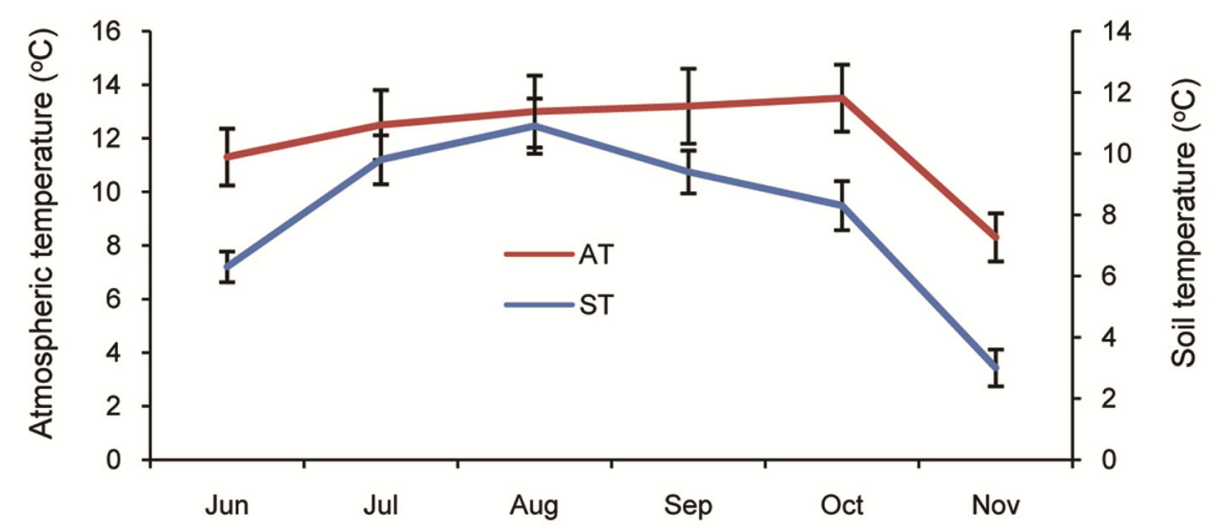

Figure 9. Air and soil temperature across the study period in 2017 in a Betula utilis (birch) forest stand.

features of shoot growth phenology. Leaves were more densely packed along shoot length at treeline species $(0.8$ versus 1.2 leaves/cm shoot length).

Treeline species at Tungnath were relatively poor in leaf $\mathrm{N}$ at mature stage than the mid-altitude forest trees $(2.5 \text { versus } 1.7 \%)^{33}$. Studies conducted elsewhere have shown that nutrient concentration in the soil and trees decreases with increasing elevation in treeline ecotone ${ }^{34}$, and this might explain why treeline shift and global warming are decoupled ${ }^{35}$. Our data also show that both soil nutrients (total $\mathrm{N}, R^{2}=0.30$; and organic carbon (OC), $R^{2}=0.223$ ) and foliar $\mathrm{N}$ decreased with increasing elevation though the relation was weak, indicating nutrient conservation strategy of $R$. campanulatum in poor site conditions. The treeline soil OC concentration was much higher than that reported for mid-altitude forests of this region (range $=0.8-3.3 \%$ ). Soil organic carbon stock has been reported to be the highest for $B$. utilis across a variety of temperate forests of the Kashmir Himalaya $^{36}$.

\section{Rate of Rhododendron campanulatum upward movement}

In the studied elevation transect of Tungnath site (3511$3665 \mathrm{~m}$ amsl), a total of 17 adult individuals and 36 seedlings of $R$. campanulatum were found growing in 2017. About half of the $R$. campanulatum adult individuals had seedlings around their canopies. Taking the mean distance of seedlings from the mother tree (average $2.8 \mathrm{~m}$; ranges $=0.50-4.72 \mathrm{~m})$ and mean age of the seedlings (from 2 to $9 \mathrm{yrs}$; mean $=3.9 \mathrm{yr}$; determined by the number of internodes) the rate of upward advancement of $R$. campanulatum population was computed at $1.4 \mathrm{~m} / \mathrm{yr}$. The interspaces between the krummholz patches are generally being filled by regenerating individuals, which may lead to the densification of ecotone in future. However, treeline has not moved up in spite of decades of warming.

\section{Tree water relation}

The timberline (TL) forest soils were more moist than soils of mid-elevation sites (MES). The pre-dawn water potential $\left(\Psi_{\mathrm{pd}}\right)$ in the TL sites generally remained above -1.0 MPa, while values below -1.0 MPa were common in MES. At TL sites, snowmelt keeps the soil moist during pre-monsoon season (April and May), while it is generally stressful in MES because of warm temperature and scanty rainfall (less than $10 \%$ of annual rainfall).

At TL the magnitude of daily change in $\Psi$ of trees was significantly higher (from 1.07 to $1.22 \mathrm{MPa}$ ) than at low elevation sites (from 0.41 to $0.75 \mathrm{MPa}$ ). This indicates that TL species tend to keep their stomata more open and conduct leaf water more freely than ME species.

The TL species differed from ME species also in seasonal pattern of daily change of water potential. In all TL species, $\Delta \Psi$ was maximum during the rainy season which is the time when ME species have little $\Delta \Psi_{\mathrm{w}}$ (average across four species, $0.16 \mathrm{MPa}$ ). This is reflected in the rainy season soil water potential, which was $0.37 \mathrm{MPa}$ for ME sites, and between -1.28 and -1.60 for TL sites. $\Delta \Psi$ generally peaked when $\Psi_{\text {pd }}$ was above $-0.5 \mathrm{MPa}$ and tended to decline with decreasing $\Psi_{\text {pd }}$. However, A. spectabilis could maintain a $\Delta \Psi$ of $1.19 \mathrm{MPa}$ when $\Psi_{\mathrm{pd}}$ was $-1.12 \mathrm{MPa}$ at TL sites. In a study in Nepal on Q. semecarpifolia, the daily change in $\Delta \Psi$ was reported to be $0.77 \mathrm{MPa}$ at $\Psi_{\mathrm{pd}}-0.40 \mathrm{MPa}$. Fotelli et al. ${ }^{37}$ have reported $\Delta \Psi$ values up to $-1.5 \mathrm{MPa}$ in Mediterranean oaks during drought. The TL species differed from each another in the extent and timing of osmotic adjustment.

Interestingly, TL species maintained a relatively higher level of leaf conductance during the rainy season. The morning leaf conductance across all seasons and species of the treeline areas ranged between $28.75 \pm 1.45$ and $329.2 \pm 8.98 \mathrm{mmol} \mathrm{m}^{-2} \mathrm{sec}^{-1}$.

Among oaks, maximum conductance for $Q$. semecarpifolia was lower than that reported for $Q$. leucotrichophora and $Q$. floribunda, the mid-elevation oaks ${ }^{38,39}$ and 
much lower than for the deciduous oak $Q$. rubra $\left(400 \mathrm{mmol} \mathrm{m}^{-2} \mathrm{sec}^{-1}\right)^{40}$. Some other oaks maintain high conductance with low water potential. For example, $Q$. dumosa (L.) has a conductance of $80 \mathrm{mmol} \mathrm{m}^{-2} \mathrm{sec}^{-1}$ at $-3.34 \mathrm{MPa}$ (ref. 41), Q. coccifera (L.) has a conductance of $150 \mathrm{mmol} \mathrm{m}^{-2} \mathrm{sec}^{-1}$ at $-3.0 \mathrm{MPa}$, and $Q$ douglasii has a conductance of $>200 \mathrm{mmol} \mathrm{m}^{-2} \mathrm{sec}^{-1}$ at $-3.6 \mathrm{MPa}$ (ref. 42). B. utilis appears to make maximum use of the late spring and summer season, and maintains a high morning leaf conductance. In $R$. arboreum the morning conductance ranges between $44.43 \pm 1.15$ and $216.0 \pm$ $3.79 \mathrm{mmol} \mathrm{m}^{-2} \mathrm{sec}^{-1}$ which is comparable with the range 28-219 mmol m $\mathrm{mec}^{-1}$ reported by Poudyal et al. ${ }^{43}$ and Tewari $^{44}$ from the lower Himalayan sites.

\section{Tree ring width chronology}

The tree ring study on silver fir (A. spectabilis) indicates the absence of recruitment during the past four decades of rapid warming. Rai et al. ${ }^{45}$ also reported the absence of natural regeneration of silver fir community above the forest limit. This is contrary to recent treeline advancement reported from some Himalayan sites in India ${ }^{46,47}$ and $\mathrm{Nepal}^{7,8,48,49}$.

Grazing by herbivores has been taken as an important determinant of treeline position and tree growth and population structure elsewhere ${ }^{50,51}$ and could be a potentially important factor in the mesic area as young Abies individuals have some forage value and may be susceptible to grazing by wild and domestic herbivores ${ }^{52}$. In a study in the Swiss Alps, land abandonment was reported to be the principal driver of treeline rise, and only a small fraction of upward shift was reported to be due to climate change ${ }^{53}$.

The tree-ring width in fir was positively correlated with winter (December-February) temperature, and negatively correlated with temperature of the pre-monsoon month, i.e. May. However, pre-monsoon (April-May) precipitation had a favourable effect on tree-ring growth, indicating that pre-monsoon warming could favour growth when it is accompanied by moisture. The positive response of tree growth to winter temperature observed in this study is similar to growth behaviour in some other sites of the Himalaya, viz. Western Himalaya ${ }^{47,54}$, Nep$\mathrm{al}^{55,56}$, Sikkim ${ }^{57}$ and Tibet ${ }^{5-60}$. Favourable influence of winter temperature on growth of an evergreen species is rather contrary to general understanding, which dismisses any role of winter temperature as a factor controlling treelines ${ }^{6}$. There are also data from several sites from other mountain regions to indicate that winter warming is a driver of the upslope advance of treeline ${ }^{61}$. The increased temperatures in winter and early spring might favour photosynthesis and other physiological activities that lead to early initiation of cambium formation and division $^{62,63}$. Observations of the present study on tree water relations indicate that the trees actively conduct water, withdrawing soil water from deeper unfrozen soil during relatively warm hours of sunny days.

\section{Early snowmelt effect}

Plant growth period (period from the beginning of growth to the time when about $80 \%$ of plant shoots have senesced) was about 5-6 months from about mid-April to mid-October. This is longer for a mountain region of warm temperate latitudes. Even within 5-6 months growing period, growth initiation in the species was staggered.

The total species number in the study area of Tungnath site increased as the growth period progressed from 44 in May to 80 in September. The peak species richness in early snowmelt microsites (average $21.8 \pm 0.4$ species $\mathrm{m}^{-2}$ ) was significantly higher than in the late snow melt microsites (average 17.6 \pm 0.6 species $\mathrm{m}^{-2}$ ), indicating the positive effect of longer and favourable growth period on species diversity. The plant growth in treeline and alpine areas is influenced by the timing of snowmelt, post snowmelt temperature and soil moisture ${ }^{64}$. In Tungnath, temperature is becoming warmer due to global change and soil moisture is constantly high during this period $^{16,21}$. Sites where snowmelt occurs earlier, are more productive and species-rich than those where snowmelt is delayed $^{65-68}$.

\section{Livelihood interventions}

The timberline ecotones and their nearby areas in Central Himalaya remain under anthropogenic pressure due to the resource use by people, often resulting in an ecosystem degradation. There is evidence to indicate the local extinction of birch from a shrine. In the Chopta-Tungnath treeline ecotone area, livelihood options for local communities are limited, and largely based on natural biota. Still the consumption of firewood is very high in the study area, averaging 7-8 tonnes fuelwood per household annually. In shops/restaurants serving tourists and local people, consumption goes up-to 10-14 tonnes fuelwood per year. The summertime religious tourism accounts for about $47 \%$ of income of the studied households ( 882 nos) of timberline-linked villages. Among the non-farm sources, the second major share was of business/selfemployment (income of about $33.8 \%$ with engagement of $31.25 \%$ households) connected to tourism. Of the various livelihood interventions carried out in two timberline villages, off-season vegetable cultivation in polyhouses was the most favoured (adopted by 120 families), followed by mushroom cultivation. About $1600 \mathrm{~kg}$ of vegetables and $60 \mathrm{~kg}$ of Pleurotus mushroom worth INR 35,000 and 42,000 respectively, were produced. Cultivation in polyhouses gives protection against climate 
extremes, which are on an increase in the high and remote Himalaya.

\section{Conclusion and management implications}

Though evidences for the upslope movement of treeline at the study sites (Kashmir, Uttarakhand and Sikkim) are lacking, densification of treeline ecotone and advancement of krummholz species ( $R$. campanulatum) into alpine meadows are noticeable. Both can be a serious threat to the diversity and integrity of alpine meadows. The increased woody cover may bring about several changes, such as the reduction in albedo and daytime cooling of soil. Livestock grazing is already on a decline in the Himalaya ${ }^{7}$, and wild mammal grazing in timberline areas is quite low because of their sparse population. However, tree-cutting for firewood still continues, and may keep the treeline stationary for some years.

By mapping timberline at the regional level, the present study has raised timberline status from a mere landmark to a widespread and dynamic biological system constantly influencing and exchanging with alpine grasslands on its higher side (alpine meadows). Equally fascinating could be the processes occurring within ecotones involving krummholz patches, woody mats of juniper, and ecosystems dominated by herbs. What steps can be taken to initiate the management of these long segments of vegetation? First, there is need to identify large meadow areas where species could survive. Second, establish a longterm study programme on selected sites to document and understand temporal and spatial dynamics over an appropriately long time. Biota of these high-altitude areas have a high percentage of endemic species, many remaining restricted to a single $100 \mathrm{~m}$ elevation band (e.g. 46 species in Kashmir). Threat analysis, as done for some species in the high ranges of Uttarakhand ${ }^{17}$, is a necessary step towards conservation. Rarity analysis of native species as done for high-altitude areas of Uttarakhand ${ }^{17}$ could be a useful step towards conservation priorities. About $27 \%$ of the species of this part are locally scarce with narrow ecological amplitude; hence they are at high risk of extinction in a situation characterized by highly uncertain future.

Our data show that TLR is lower, particularly during some autumn-winter months, than generally perceived. Studies are necessary to analyse whether the low TLR is related to climate warming which is more in higher elevations than the lower elevations, resulting in the reduction of their temperature difference. Winters in the Himalaya are already $\operatorname{mild}^{69}$, allowing evergreen tree species to carry out photosynthesis, particularly on sunny days. The positive response of tree-ring growth in $A$. pindrow to winter temperature might suggest that the fir is likely to be favoured by EDW. Birch, on the other hand, is getting adversely affected by intensified pre-monsoon drought under the influence of global warming ${ }^{22}$.

1. Singh, S. P., Khadka, I. B., Karky, B. and Sharma, E., Climate change in the Hindu Kush-Himalayan: the state of current knowledge. International Centre for Integrated Mountain Development, Kathmandu, Nepal, 2011.

2. Yao, T. et al., Different glacier status with atmospheric circulations in Tibetan Plateau and surroundings. Nature Climate Change, 2012, 2, 663-667; doi:10.1038/NCLIMATE1580.

3. Wester, P., Mishra, A., Mukherji, A. and Shrestha, A. B. (eds), The Hindu Kush Himalaya Assessment-Mountains, Climate Change, Sustainability and People, Springer Nature, Switzerland AG, Cham, 2019.

4. Miehe, G., Miehe, S., Vogel, J., Co, S. and La, D., Highest treeline in the northern hemisphere found in southern Tibet. Mt. Res. Dev., 2007, 27, 169-173.

5. Greenwood, S. and Jump, A., Consequences of treeline shifts for the diversity and function of high altitude ecosystems. Arct. Antarct. Alp. Res., 2014, 46(4), 829-840.

6. Körner, C. and Paulsen, J., A world-wide study of high altitude treeline temperatures. J. Biogeogr., 2004, 31, 713-732.

7. Gaire, N. P., Koirala, M., Bhuju, D. R. and Borgaonkar, H. P., Treeline dynamics with climate change at the central Nepal Himalaya. Climate Past, 2014, 10(4), 1277-1290.

8. Liang, E., Wang, Y., Eckstein, D. and Luo, T., Little change in the fir tree-line position on the southeastern Tibetan Plateau after 200 years of warming. New Phytol., 2011, 190, 760-769.

9. Liu, G., Du, S., Peng, S. and Wang, G., Rainfall interception in two contrasting forest types in the Mount Gongga area of Eastern Tibet, China. Hydrol. Curr. Res., 2013, 4, 161; doi:10.4172/21577587.1000161.

10. Schickhoff, U. et al., Do Himalayan treelines respond to recent climate change? an evaluation of sensitivity indicators. Earth Syst. Dyn., 2015, 6, 245-265.

11. Holtmeier, F. K., Mountain Timberlines. Ecology, Patchiness, and Dynamics, Springer Berlin, Germany, 2009.

12. Körner, C., Treelines will be understood once the functional difference between a tree and a shrub is. Ambio, 2012, 41(3), 197-206.

13. Shrestha, U. B., Gautam, S. and Bawa, K. S., Widespread climate change in the Himalayas and associated changes in local ecosystems. PLoS ONE, 2012, 7(5), e36741.

14. Singh, S. P. and Gumber, S., Climate change in Himalayas: research findings and complexities. Int. J. Plant Environ., 2018, 4(1), 81-88.

15. Latwal, A., Sah, P. and Sharma, S., A cartographic representation of a timberline, treeline and woody vegetation around a central Himalayan summit using remote sensing method. Trop. Ecol., 2018, 59(2), 177-186.

16. Joshi, R., Kumar, S. and Singh, S. P., Near surface temperature lapse rate for treeline environment in western Himalaya and possible impacts on ecotone vegetation. Trop. Ecol., 2018, 59(2), $1-13$.

17. Rawal, R. S., Rawal, R., Rawat, B., Negi, V. S. and Pathak, R., Plant species diversity and rarity patterns along altitude range covering treeline ecotone in Uttarakhand: conservation implications. Trop. Ecol., 2018, 59(2), 225-239.

18. Pandey, A., Rai, S. and Kumar, D., Changes in vegetation attributes along an elevation gradient towards timberline in Khangchendzonga National Park, Sikkim. Trop. Ecol., 2018, 59(2), 259-271.

19. Nanda, S. A., Reshi, Z. A., Haq, M. U., Lone, B. A. and Mir, S. A., Taxonomic and functional plant diversity patterns along an 
elevational gradient through treeline ecotone in Kashmir. Trop. Ecol., 2018, 59(2), 211-224.

20. Singh, P. and Negi, G. C. S., Treeline species phenology: shoot growth, leaf characteristics and nutrient dynamics. Trop. Ecol., 2018, 59(2), 297-311.

21. Tewari, A., Shah, S., Singh, N. and Mittal, A., Treeline species in Western Himalaya are not water stressed: a comparison with low elevation species. Trop. Ecol., 2018, 59(2), 313-325.

22. Singh, U. et al., Static tree line of Himalayan silver fir since last several decades at Tungnath, western Himalaya. Trop. Ecol., 2018, 59(2), 351-363.

23. Adhikari, B. S., Kumar, R. and Singh, S. P., Early snowmelt impact on herb species composition, diversity and phenology in a western Himalayan treeline ecotone. Trop. Ecol., 2018, 59(2), 365-382.

24. Singh, S. P. and Rawal, R. S., Manuals of Field Methods, Central Himalayan Environment Association, Nainital, 2017.

25. Singh, R. D., Tewari, P., Dhaila, P. and Tamta, K. K., Diversifying livelihood options of timberline resource dependent communities in Uttarakhand Himalayas - conservation and development implications. Trop. Ecol., 2018, 59(2), 327-338.

26. Pandey, A., Badola, H. K., Rai, S. and Singh, S. P., Timberline structure and woody taxa regeneration towards treeline along latitudinal gradients in Khangchendzonga National Park, Eastern Himalaya. PLoS ONE, 2018, 13(11), e0207762.

27. Rawal, R. S. and Dhar, U., Sensitivity of timberline flora of Kumaun Himalaya, India: conservation implications. Arct. Alp. Res., 1997, 29, 112-121.

28. Sharma, C. M., Mishra, A. K., Prakash, O., Dimri, S. and Baluni, P., Assessment of forest structure and woody plant regeneration on ridge tops at upper Bhagirathi basin in Garhwal Himalaya. Trop. Plant Res., 2014, 1, 62-71.

29. Acharya, B. K., Chettri, B. and Vijayan, L., Distribution pattern of trees along an elevation gradient of Eastern Himalaya, India. Acta Oecol., 2011, 37, 329-336.

30. Gairola, S., Rawal, R. S. and Todaria, N. P., Effect of anthropogenic disturbance on vegetation characteristics of sub-alpine forests in and around Valley of Flowers National Park, a world heritage site of India. Trop. Ecol., 2015, 56(3), 357-365.

31. Sharma, C. M., Mishra, A. K., Tiwari, O. P., Krishan, R. and Rana, Y. S., Effect of altitudinal gradients on forest structure and composition on ridge tops in Garhwal Himalaya. Energy, Ecol. Environ., 2017, 2(6), 404-417.

32. Negi, G. C. S., Leaf and bud demography and shoot growth in evergreen and deciduous trees of central Himalaya, India. Trees: Struct. Funct., 2006, 20, 416-429.

33. Negi, G. C. S., Phenology and nutrient dynamics in tree leaves of Kumaun Himalayan Forests. Ph.D. thesis, Kumaun University, Nainital, 1989.

34. Drollinger, S., Müller, M., Kobl, T., Schwab, N., Bohner, J., Schickhoff, U. and Scholten, T., Decreasing nutrient concentrations in soils and trees with increasing elevation across a treeline ecotone in Rolwaling Himal, Nepal. J. Mt. Sci., 2017, 14, $843-$ 858.

35. Müller, M., Schwab, N., Schickhoff, U., Böhner, J. and Scholten, T., Soil temperature and soil moisture patterns in a Himalayan alpine treeline ecotone. Arct. Antarct. Alp. Res., 2016, 48, 501521.

36. Dar, J. A. and Somaiah, S., Altitudinal variation of soil organic carbon stocks in temperate forests of Kashmir Himalayas, India. Environ. Monit. Assess., 2015, 187(2), 11.

37. Fotelli, M. N., Radoglou, K. M. and Constantinidou, H. I. A., Water stress responses of seedlings of four Mediterranean oak species. Tree Physiol., 2000, 20, 1065-1075.

38. Garkoti, S. C., Zobel, D. B. and Singh, S. P., Comparison of water relations of seedlings and trees of two Himalayan Oaks. Int. J. Ecol. Environ. Sci., 2000, 26, 213-222.
39. Tewari, A., Water status measurements in a banj oak (Quercus leucotrichophora A. Camus) forest in Kumaun central Himalayas. J. Environ. Biol., 2000, 21, 23-27.

40. Kubiske, M. E. and Abrams, M. D., Photosynthesis, water relations and leaf morphology of xeric versus mesic Quercus rubra ecotype in central Pennsylvania in relation to moisture stress. Can. J. For. Res., 1992, 22, 1402-1407.

41. Hastings, S. J., Oechel, W. C. and Sionit, N., Water relations and photosynthesis of chaparral resprouts and seedlings following fire and hand clearing. In The California Chaparral-Paradigms Reexamined (ed. Keeley, S. C.), Natural History Museum of Los Angeles County, No. 34, Science Series, Los Angeles, CA, 1989, pp. 107-113.

42. Xu, L. and Baldocchi, D. D., Seasonal trends in photosynthetic parameters and stomatal conductance of blue oak (Quercus douglasii) under prolonged summer drought and high temperature. Tree Physiol., 2003, 23, 865-877.

43. Poudyal, K., Jha, P. K., Zobel, D. B. and Thapa, C. B., Patterns of leaf conductance and water potential of five Himalayan tree species. Tree Physiol., 2004, 24, 689-699.

44. Tewari, A., Timing of drought: effects on water relation of certain major forest types of lower and middle central Himalaya. Ph.D. thesis, Kumaun University, Nainital, 1998.

45. Rai, I. D., Adhikari, B. S., Rawat, G. S. and Bargali, K., Community structure along timberline ecotone in relation to microtopography and disturbances in Western Himalaya. Not. Sci. Biol., $2012,4(2), 41-52$.

46. Dubey, B., Yadav, R. R., Singh, J. and Chaturvedi, R., Upward shift of Himalayan pine in Western Himalaya, India. Curr. Sci., 2003, 85, 1135-1136.

47. Yadava, A. K. et al., Altitudinal treeline dynamics of Himalayan pine in western Himalaya, India. Quaternary Int., 2017, 444, 4452.

48. Gaire, N. P., Dhakal, Y. R., Lekhak, H. C., Bhuju, D. R. and Shah, S. K., Dynamics of Abies spectabilis in relation to climate change at the treeline ecotone in Langtang National Park, Nepal. J. Sci. Technol., 2011, 12, 220-229.

49. Tiwari, A., Fan, Z. X., Jump, A. S., Li, S. F. and Zhou, Z. K., Gradual expansion of moisture sensitive Abies spectabilis forest in the Trans-Himalayan zone of central Nepal associated with climate change. Dendrochronologia, 2017, 41, 34-43.

50. Cairns, D. M., Lafon, C., Moen, J. and Young, A., Influences of animal activity on treeline position and pattern: implications for treeline response to climate change. Phys. Geogr., 2007, 28, 419433.

51. Speed, J. D. M., Austrheim, G., Hester, A. J. and Mysterud, A., Growth limitation of mountain birch caused by sheep browsing at the altitudinal treeline. For. Ecol. Manage., 2011, 261, 13441352.

52. Shrestha, K. B., Hofgaard, A. and Vandvik, V., Recent treeline dynamics are similar between dry and mesic areas of Nepal, central Himalaya. J. Plant Ecol., 2015, 8(4), 347-358; doi: 10.1093/jpe/rtu035.

53. Gehrig-Fasel, J., Guisan, A. and Zimmermann, N. E., Tree line shifts in the Swiss Alps: climate change or land abandonment? J. Veg. Sci., 2007, 18, 571-582.

54. Borgaonkar, H. P., Ram, S. and Sikder, A. B., Tree-ring analysis of high elevation Cedrus deodara D. Don from Western Himalaya in relation to climate and glacier fluctuations. Dendrochronologia, 2009, 27, 59-69.

55. Bräuning, A., Tree-ring studies in the Dolpo-Himalaya (western Nepal). TRACE-tree rings in archaeology. Climatol. Ecol., 2004, 2, 8-12.

56. Chhetri, P. K., Bista, R. and Cairns, D. M., Population structure and dynamics of Abies spectabilis at treeline ecotone of Barun Valley, Makalu Barun National Park, Nepal. Acta Ecol. Sin., 2016, 36, 269-274. 
57. Bhattacharyya, A. and Chaudhary, V., Late-summer temperature reconstruction of the eastern Himalayan region based on treering data of Abies densa. Arct. Antarct. Alp. Res., 2003, 35, 196-202.

58. Liu, J. J., Yang, B., Huang, K. and Sonechkin, D. M., Annual regional precipitation variations from a 700 year tree-ring record in south Tibet, western China. Climate Res., 2012, 53(1), 25-41.

59. Wang, X., Zhang, Q. B., Ma, K. and Xiao, S., A tree-ring record of 500-year dry-wet changes in northern Tibet, China. Holocene, 2008, 18(4), 579-588

60. Yang, B., Qin, C., Wang, J., He, M., Melvin, T. M., Osborn, T. J. and Briffa, K. R., A 3,500-year tree-ring record of annual precipitation on the northeastern Tibetan Plateau. Proc. Natl. Acad. Sci. USA, 2014, 111(8), 2903-2908.

61. Harsch, M. A., Hulme, P. E., McGlone, M. S. and Dunca, R. P., Are treelines advancing? A global meta-analysis of treeline response to climate warming. Ecol. Lett., 2009, 12, 1040-1049.

62. Fritts, H. C., Tree Rings and Climate, Academic Press, New York, USA, 1976, p. 567.

63. Tranquillini, W., The physiology of plants at high altitude. Annu. Rev. Plant Physiol., 1964, 15, 345-362.

64. Winkler, D. E., Butz, R. J., Germino, M. J., Reinhardt, K. and Kueppers, L. M., Snowmelt timing regulates community composition, phenology and physiological performance of alpine plants. Front. Plant Sci., 2018, 9, 1140; doi:10.3389/fpls.2018.01140.

65. Kudo, G., Effects of snow-free period on the phenology of alpine plants inhabiting snow patches. Arct. Antarct. Alp. Res., 1991, 23, 436-443.

66. Stanton, M. L., Rejmanek, M. and Galen, C., Changes in vegetation and soil fertility along a predictable snowmelt gradient in the Mosquito Range, Colorado, USA. Arct. Alp. Res., 1994, 26, 364-374.

67. Litaor, M. I., Williams, M. and Seastedt, T. R., Topographic controls on snow distribution, soil moisture, and species diversity of herbaceous alpine vegetation, Niwot ridge, Colorado. J. Geophys. Res.: Biogeosci., 2008, 113, G02008; doi:10.1029/2007JG000419.

68. Nabe-Nielsen, J., Normand, S., Hui, F. K. C., Stewart, L., Bay, C., Nabe-Nielsen, L. I. and Schmidt, N. M., Plant community composition and species richness in the high arctic tundra: from the present to the future. Ecol. Evol., 2017, 7(23), 10233-10242; doi:10.1002/ece3.3496.

69. Sakai, A. and Malla, S. B., Winter hardiness of tree species at high altitudes in the East Himalaya, Nepal. Ecology, 1981, 62, 12881298.

ACKNOWLEDGEMENTS. This study was carried out as part of the Indian Himalayan Timberline Research (IHTR) project. The financial support received under the National Mission on Himalayan Studies (NMHS), Ministry of Environment, Forest and Climate Change, Government of India is duly acknowledged. We thank the Co-ordinator, IHTRP project and Director, GBPNIHESD, Gangtok for providing the necessary facilities to conduct this study. We also thank the Project Management Unit (Central Himalayan Environment Association) of IHTR, Uttarakhand Forest Department, and the Director, HAPPRC, Srinagar for support in implementation of the study.

doi: $10.18520 / \mathrm{cs} / \mathrm{v} 120 / \mathrm{i} 5 / 859-871$ 